
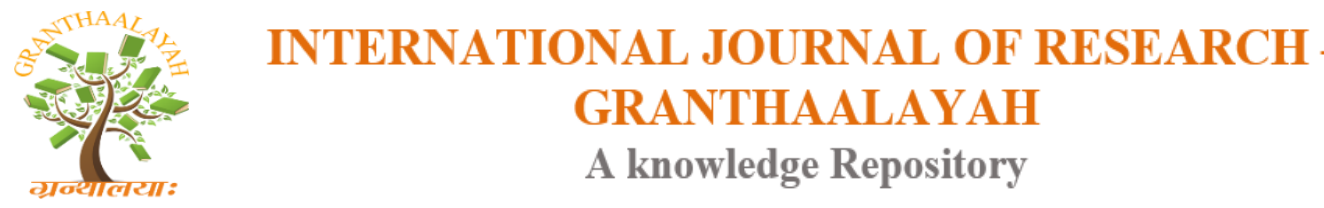

Management

\title{
RISK ANALYSIS OF COCONUT PRODUCT MARKETING
}

\author{
Ine Fausayana *1, Weka Gusmiarty Abdullah ${ }^{1}$, La Ode Dawid ${ }^{1}$ \\ ${ }^{1}$ Department of Agribusiness, Faculty of Agriculture. Universitas Halu Oleo, Kendari, Southeast \\ Sulawesi Indonesia 93232
}

\begin{abstract}
The aim of this study was to analysis the risks of coconut products marketing in Kendari City. The results of this study described risk identification in three stage of marketing of coconut product, namely (a) Five risks identified at the stage of storaging; broken coconut fruit, unsold product, fire market, theft of coconut fruits, and market regulation; (b) Three risks identified at the stage of processing; broken coconut, coconut shell waste, and damage to processing facilities; and (c) Four risks identified at the stage of selling; unsold product, non-strategic selling locations, substitute goods, and competitors. Overall, the risk on coconut products marketing was mapped at low risk. High risk was more prevalent in the stage of processing, which was caused by the risk of coconut shell waste. While medium risk was more prevalent in the stage of storaging.
\end{abstract}

Keywords: Coconut Products; Risk; Risk Level; Risk Probability.

Cite This Article: Ine Fausayana, Weka Gusmiarty Abdullah, and La Ode Dawid. (2018). "RISK ANALYSIS OF COCONUT PRODUCT MARKETING." International Journal of Research Granthaalayah, 6(5), 138-148. https://doi.org/10.29121/granthaalayah.v6.i5.2018.1435.

\section{Introduction}

Coconut is very important in the economy as a provider of employment, raw materials for domestic industry and direct consumption (Damanik, 2007). Usually coconut plantations are located in the area between 0-200 m, whereas most people's palm is located between 200-500 m. Areas that are too high will cause the growth to be too slow and the fruit less satisfactory (Ruauw, et al. 2011). Coconut by-products can also be used as construction materials, raw materials for household appliances and fuels (PARDI, 2011).

According to Jumiati, et al. (2013), coconut tree is known as the tree of life, hence this plant has high economic value. Wowor, et al (2007) coconut fruit is the main product of coconut products that are widely used by human for generations that can provide added value. Almost all parts of the coconut plant can be utilized by humans. Like other agricultural products, coconut marketing also has risks. The sources of risk faced by agribusiness actors include quality risk, production and market risk (Suharjito, et al, 2010). 
Other researchers on the risk of agribusiness both upstream and downstream agribusiness has been done by several researchers in several places. Drakel (2010) about marketing margin, Hidayat, et al. (2012) conducted a study entitled 'Risk Identification Model and Increase Value Added Strategy on Oil Palm Supply Chain'. Zhang, et al. (2014) conducts research that is aligned to the supply chain under the title 'Risk Assessment of Agricultural Products Supply-Chain Finance based on D-S Theory'. Toledo, et al. (2011) conducts research in areas of risk that focus on risk factors in agriculture.

Risk will arise from the unpredictable predictability of agricultural product prices. According to Abdullah (2015), this situation arises as a result of speculation sellers who tend to want to get big profits and marketing chain. This risk has to be controlled because otherwise there will be an opportunity problem on the supply of materials that resulted in financial losses to the company (Zsidisin, et al., 2008). While the risk on brown sugar is found that all of risks at the stage of cooking and marketing were in low risk category. The experience of farmers will reduce the risk on farming (Fausayana et al 2017; 2018).

\section{Material and Method}

This study was conducted in Kendari City, South East Sulawesi, Indonesia. Kendari City is the capital of Southeast Sulawesi Province (Sultra) with the function as the center of economic circulation and government. The populations referred to in this study are all sellers of grated coconut, young coconut and young coconut ice.

Risk analysis was done by identified and map the risk of coconut product marketing, descriptively. Risk analysis was started by indentified the risk through in-depth interviews about the potential risk registered, risk type, risk source, risk probability and risk consequence.

The next step, risks of coconut product marketing were mapped on the basis of data on probability risks and consequences. It could be seen in Table 1.

Table 1: Risk Mapping

\begin{tabular}{|l|l|l|}
\hline Category of Risk probability & Category of Consequence & Mapping Risk \\
\hline Low & Low & Low risk \\
\hline & High & Medium risk \\
\hline High & Low & Medium risk \\
\hline & High & High risk \\
\hline
\end{tabular}

\section{Result and Discussion}

\section{The Stage of Storaging}

Storage was one of the most influential parts in coconut products marketing. The locations and methods of storage were very influential on the quality of coconut fruits. The purchased coconut fruits were not sold directly, but it was stored for inventory. The purpose of storage was to reduce the purchase intensity and reduce the risk at the stage of purchase. The storage of coconut fruit was done in various ways, such as by storing it in a wooden casket and some of seller just covered it with plastic sheeting. 
The risk that often occurs in the storage of coconut fruit was the damage of coconut fruits (rot or broken), coconut fruit left behind, theft of coconut fruit, market fire, and market control by the government. It was a challenge to survive in the marketing of coconut products. Clearly, the risks at the stage of storaging of coconut products could be seen in Table 2 .

Table 2: List of Risks at the Stage of Storaging

\begin{tabular}{|c|c|c|c|c|}
\hline No. & Risk Register & Risk Type & Risk Source & Products \\
\hline 1. & $\begin{array}{l}\text { Broken coconut } \\
\text { fruit }\end{array}$ & $\begin{array}{l}\text { Pure, } \\
\text { Non-transferable } \\
\text { Physical }\end{array}$ & $\begin{array}{l}\text { Inappropriate transportation } \\
\text { methods, } \\
\text { Incorrect storage method }\end{array}$ & $\begin{array}{l}\text { Grated coconut } \\
\text { Young } \\
\text { coconut ice } \\
\text { Young } \\
\text { coconut }\end{array}$ \\
\hline 2. & Unsold product & $\begin{array}{l}\text { Pure, } \\
\text { Non-transferable } \\
\text { Physical }\end{array}$ & $\begin{array}{l}\text { Slow sales rotation, } \\
\text { Coconut fruit was not sold, } \\
\text { Decrease in the quality of } \\
\text { coconut fruits }\end{array}$ & $\begin{array}{l}\text { Grated coconut } \\
\text { Young } \\
\text { coconut ice } \\
\text { Young } \\
\text { coconut }\end{array}$ \\
\hline 3. & Fire market & $\begin{array}{l}\text { Pure, } \\
\text { Could } \\
\text { transferred, } \\
\text { Physical }\end{array}$ & $\begin{array}{l}\text { human error } \\
\text { Short circuit of electric current }\end{array}$ & $\begin{array}{l}\text { Grated coconut } \\
\text { Young } \\
\text { coconut ice } \\
\text { Young } \\
\text { coconut }\end{array}$ \\
\hline 4. & $\begin{array}{l}\text { Theft of coconut } \\
\text { fruits }\end{array}$ & $\begin{array}{l}\text { Pure, } \\
\text { Non-transferable } \\
\text { Social }\end{array}$ & $\begin{array}{l}\text { Poor Moral and mental of } \\
\text { society, } \\
\text { Negligence of the seller in save } \\
\text { their goods }\end{array}$ & $\begin{array}{l}\text { Grated coconut } \\
\text { Young } \\
\text { coconut ice } \\
\text { Young } \\
\text { coconut }\end{array}$ \\
\hline 5. & $\begin{array}{l}\text { Market } \\
\text { regulation }\end{array}$ & $\begin{array}{l}\text { Speculation, } \\
\text { Can be } \\
\text { transferred, } \\
\text { Social }\end{array}$ & Irregular market environment & $\begin{array}{l}\text { Grated coconut } \\
\text { Young coconut }\end{array}$ \\
\hline
\end{tabular}

Table 2 showed that in the storage of coconuts, there were identified five risks. It causes the loss in coconut product marketing.

Broken coconut fruit was already a consequence for the seller of coconut products. It was a pure risk and an accidental risk. It was mostly experienced by sellers of grated coconut because coconuts that have been peeled were vulnerable to rupture and pathogens. The risk of broken coconut was a risk that could not be transferred to other parties, only the coconut seller who beared the loss. The risk was caused by improper transportation methods that caused coconut collided and broken. The broken coconuts were also caused by improper storage methods. The coconuts were kept irregular and covered with tarpaulins.

The coconut fruit that was stored has uncertainty in the market absorption, the slow sales rotation of coconut marketing. It caused coconut left behind in the storage in long time so its quality decreased and broken. It was clasified in pure risk and non-transferable risk. The scary risk for 
coconut sellers was the risk of market fire because it could loss all assets and marketing tools. The risk of market fire was clasified in pure risk. The short circuit of electric current or human error were source risk of market fire. The risk of fire included physical risk that could be transferred to another party by registering their business with the insurance company.

Regardless of the physical risk of storaging the coconuts, a very worrying risk for the coconut seller was social risk such as theft. The source risk was poor mental and morals of society. The other source risk was the negligence of coconut sellers in save their goods. It creates opportunities for people with poor morale to theft.

Market is a public means that organize is organized by the government. In this condition, market regulation in creating a beautiful and comfortable market environment was be a risk for coconut sellers. It caused the coconut seller did not get the strategic location as they want. The risk of regulation market classified in speculation risk that can not and non-transferable risk to other parties. The risk of market regulation was also categorized in social risk caused by the irregular behavior of the seller.

Storaging of coconut fruits has constraints in the form of risks that have loss probability for coconut sellers. The risks at the stage of storaging could be calculated the probability of the occurrence and the magnitude of the consequences of the losses it causes to mapping the risk at the stage of storaging. It could be seen in Table 3.

Table 3 showed that two identifiable risks directly affect the marketing advantage at the stage of storaging in marketing of coconut products, i.e. the risk of broken coconut fruits and the risk of fruits left behind in storages. The coconuts fruits that left behind in storage were the risk of losing the seller of coconut products. The highest probability risk and consequence of the unsold coconut was in the surplus period. While the lowest probability risk and consequence was in critical period.

Young coconut sales also have loss probability in each sales period. The highest probability risk and consequence occurred during the surplus selling period, while the lowest probability and consequence was in the critical selling. Howecer, the risk of coconuts left behind in storage did not experienced by the sellers of young coconut ice. It was due to a small amount of purchases and a quick sales circulation in marketing of young coconut ice.

Table 3: Mapping of Risk of Coconut Products at the Stage of Storaging

\begin{tabular}{|c|c|c|c|c|c|c|c|c|}
\hline \multirow[t]{2}{*}{ No. } & \multirow{2}{*}{$\begin{array}{l}\text { Risk } \\
\text { register }\end{array}$} & \multirow{2}{*}{$\begin{array}{l}\text { Product } \\
\text { type }\end{array}$} & \multirow{2}{*}{$\begin{array}{l}\text { Sale } \\
\text { period }\end{array}$} & \multicolumn{2}{|c|}{ Probability } & \multicolumn{2}{|c|}{ Consequence } & \multirow{2}{*}{$\begin{array}{l}\text { Mapping } \\
\text { Risk }\end{array}$} \\
\hline & & & & $(\%)$ & Category & (\$) & Category & \\
\hline \multirow[t]{7}{*}{1.} & \multirow{7}{*}{$\begin{array}{l}\text { Unsold } \\
\text { product }\end{array}$} & \multirow{3}{*}{$\begin{array}{l}\text { Grated } \\
\text { coconut }\end{array}$} & Normal & 0.81 & Low & 3.80 & Low & Low risk \\
\hline & & & surplus & 0.89 & Low & 6.83 & Low & Low risk \\
\hline & & & Critical & 0.80 & Low & 2.80 & Low & Low risk \\
\hline & & \multirow{4}{*}{$\begin{array}{l}\text { Young } \\
\text { coconut }\end{array}$} & Normal & 2.26 & Low & 4.53 & Low & Low risk \\
\hline & & & surplus & 2.66 & Low & 11.70 & High & Medium \\
\hline & & & Critical & 1.84 & Low & 2.31 & Low & risk \\
\hline & & & & & & & & Low risk \\
\hline
\end{tabular}




\begin{tabular}{|c|c|c|c|c|c|c|c|c|}
\hline 2. & $\begin{array}{l}\text { Broken } \\
\text { coconut } \\
\text { fruit }\end{array}$ & $\begin{array}{l}\text { Grated } \\
\text { coconut }\end{array}$ & $\begin{array}{l}\text { Normal } \\
\text { surplus } \\
\text { Critical }\end{array}$ & $\begin{array}{l}4.99 \\
5.37 \\
4.70\end{array}$ & $\begin{array}{l}\text { Low } \\
\text { Low } \\
\text { Low }\end{array}$ & $\begin{array}{l}23.26 \\
41.44 \\
16.38\end{array}$ & $\begin{array}{l}\text { High } \\
\text { High } \\
\text { Low }\end{array}$ & $\begin{array}{l}\text { Medium } \\
\text { risk } \\
\text { Medium } \\
\text { risk } \\
\text { Low risk }\end{array}$ \\
\hline
\end{tabular}

The risk of broken coconut was only occuring in the marketing of grated coconut. The highest probability risk and consequence occurred in the surplus period. While the critical period has the smallest probability risk and consequence.

Table 3 also showed that most of the risks at the stage of storaging were mapped to low-risk categories. It was based on the probability of occurrence of risks and consequences in the low category. The risk of unsold products on the marketing of grated coconut in all sales periods was mapped at low risk. So, this risk could be ignored by the seller because it has no significant effect on the profit earned. There were several risks mapped in the medium category, including the risk of unsold products on young coconut marketing in the surplus sales period, and the risk of broken coconut product in the marketing of grated coconut in the surplus and normal sales period. Such risks need to be managed by sellers of coconut products so as not to affect the profitability of the sale.

\section{The Stage of Processing}

The stage of processing was a condition in which the coconut seller increases the added value of the coconut fruits. Processing of coconut fruit was done through preparation of processing facilities; then the selection of coconut fruit that will be processed; further clean of the surface of coconut fruit; in marketing of grated coconut, coconut was grated in the next step; in marketing of young coconut ice, Young coconut was mixed with other ice additives such as white sugar or brown sugar and milk.

The processing of coconut fruit in coconut product marketing has risks that influenced the sustainability of business and marketing profit of coconut products. Several risks that have been identified at the stage of processing among others broken coconut during processing, coconut wastes, and damage to processing facilities. Identified risks at the stage of procesing could be seen in Table 4.

Table 4: List of Risks at the Stage of Processing

\begin{tabular}{|l|l|l|l|l|}
\hline No. & Risk register & Risk type & Risk source & Product \\
\hline 1. & Broken coconut & $\begin{array}{l}\text { Pure } \\
\text { Non- } \\
\text { transferable } \\
\text { Physical }\end{array}$ & $\begin{array}{l}\text { Poor quality of coconut } \\
\text { Poor quality of the tools and } \\
\text { facilities in processing } \\
\text { Inappropriate management } \\
\text { methods }\end{array}$ & $\begin{array}{l}\text { Grated } \\
\text { coconut }\end{array}$ \\
\hline 2. & Coconut shell waste & $\begin{array}{l}\text { Speculative, } \\
\text { Non- } \\
\text { transferable } \\
\text { Physical }\end{array}$ & $\begin{array}{l}\text { Coconut fruits has a lot of waste } \\
\text { Coconut waste pollutes the } \\
\text { environment }\end{array}$ & $\begin{array}{l}\text { Young } \\
\text { coconut ice } \\
\text { Young } \\
\text { coconut }\end{array}$ \\
\hline
\end{tabular}




\begin{tabular}{|l|l|l|l|l|}
\hline 3. & $\begin{array}{l}\text { Damage to } \\
\text { processing facilities }\end{array}$ & $\begin{array}{l}\text { Pure } \\
\text { Non- } \\
\text { transferable } \\
\text { Physical }\end{array}$ & $\begin{array}{l}\text { Lack maintenance of processing } \\
\text { facilities } \\
\text { Poor quality of processing } \\
\text { facilities }\end{array}$ & $\begin{array}{l}\text { Grated } \\
\text { coconut } \\
\text { Young } \\
\text { coconut ice } \\
\text { Young } \\
\text { coconut }\end{array}$ \\
\hline
\end{tabular}

Table 4 indicated that there was three (3) identified risk at the stage of processing in coconut marketing. It caused loss of marketing effort. Broken coconut occurs at the stage of processing of coconut fruits to grated coconut. It was classified in pure risk because no profit was possible. There were several source risk that was processing skill in peeling the coconut fruits, the sharpness of the tools, the readiness of processing facilities, and poor quality of coconut fruits. Broken coconut risk was non-transferable risk, but it could be reduced by improving the processing skills of coconut seller and purchase of good quality of coconut fruits.

Processing of coconut fruits has externality in the form of coconut shell waste. It has to managed because it could disrupt environment. However, the risk of coconut shell waste could bring benefits or losses. The presence of coconut shell waste allowed others to buy it and process it into various handicraft products or fuel. Waste processing could also be done by the coconut sellers so that the waste of coconut becomes more valuable use is an benefit for them. Therefore, the risk of coconut shell waste was categorized into speculative risk. While the negative impact of these risks could not be transferred to other parties so these it was categorized into non-transferable risk.

Processing of coconut fruit used tools and supporting facilities. It has an economic life and usage capacity limits. Consequences of facilities damage were pure risks; also it was called as nontransferable risk. The risk of facilities damage could be seen based on the physical condition and the carrying capacity of its usage. The risk of facilities damage of coconut fruit was a physical risk that could reduce the profit from marketing activities of coconut products.

Risk at the stage of processing could reduce the profit (loss) of coconut sellers. The risks at the stage of processing could be calculated the probability of the occurrence and the magnitude of the consequences of the losses it causes to mapping the risk at the stage of processing. It could be seen in Table 5.

Table 5: Mapping of Risk of Coconut Products at the Stage of Processing

\begin{tabular}{|c|c|c|c|c|c|c|c|c|}
\hline \multirow[t]{2}{*}{ No. } & \multirow{2}{*}{$\begin{array}{l}\text { Risk } \\
\text { register }\end{array}$} & \multirow{2}{*}{$\begin{array}{l}\text { Product } \\
\text { type }\end{array}$} & \multirow{2}{*}{$\begin{array}{l}\text { Sale } \\
\text { Period }\end{array}$} & \multicolumn{2}{|c|}{ Probability } & \multicolumn{2}{|c|}{ Consequence } & \multirow{2}{*}{$\begin{array}{l}\text { Mapping } \\
\text { risk }\end{array}$} \\
\hline & & & & $(\%)$ & Category & $\begin{array}{l}\text { (USD/ } \\
\text { month) }\end{array}$ & Category & \\
\hline 1. & $\begin{array}{l}\text { Broken } \\
\text { coconut }\end{array}$ & $\begin{array}{l}\text { Grated } \\
\text { coconut }\end{array}$ & $\begin{array}{l}\text { Normal } \\
\text { Surplus } \\
\text { Critical }\end{array}$ & $\begin{array}{l}0.34 \\
0.37 \\
0.36\end{array}$ & $\begin{array}{l}\text { Low } \\
\text { Low } \\
\text { Low }\end{array}$ & $\begin{array}{l}1.58 \\
2.85 \\
1.26\end{array}$ & $\begin{array}{l}\text { Low } \\
\text { Low } \\
\text { Low }\end{array}$ & $\begin{array}{l}\text { Low risk } \\
\text { Low risk } \\
\text { Low risk }\end{array}$ \\
\hline 2. & $\begin{array}{l}\text { Coconut } \\
\text { shell } \\
\text { waste }\end{array}$ & $\begin{array}{l}\text { Young } \\
\text { coconut } \\
\text { ice }\end{array}$ & $\begin{array}{l}\text { Normal } \\
\text { Surplus } \\
\text { Critical }\end{array}$ & $\begin{array}{l}100.00 \\
100.00 \\
100.00\end{array}$ & $\begin{array}{l}\text { High } \\
\text { High } \\
\text { High }\end{array}$ & $\begin{array}{l}12.72 \\
22.42 \\
10.10\end{array}$ & $\begin{array}{l}\text { High } \\
\text { High } \\
\text { Low }\end{array}$ & $\begin{array}{l}\text { High risk } \\
\text { High risk } \\
\text { Medium } \\
\text { risk }\end{array}$ \\
\hline
\end{tabular}




\begin{tabular}{|l|l|l|l|l|l|l|l|}
\hline & $\begin{array}{l}\text { Young } \\
\text { coconut }\end{array}$ & $\begin{array}{l}\text { Normal } \\
\text { Surplus } \\
\text { Critical }\end{array}$ & $\begin{array}{l}100.00 \\
100.00 \\
100.00\end{array}$ & $\begin{array}{l}\text { High } \\
\text { High } \\
\text { High }\end{array}$ & $\begin{array}{l}8.33 \\
17.97 \\
5.36\end{array}$ & $\begin{array}{l}\text { Low } \\
\text { High } \\
\text { Low }\end{array}$ & $\begin{array}{l}\text { Medium } \\
\text { risk } \\
\text { High risk } \\
\text { Medium } \\
\text { risk }\end{array}$ \\
\hline
\end{tabular}

Table 5 indicated that there were two (2) identified risk at the stage of processing that affected the profit of the of coconut seller such as broken coconut and coconut sheel waste. The highest probability and consequence of broken coconut risk in grated coconut marketing occured in surplus period. While the lowest probability and consequence occurred in normal period.

The risk of coconut shell waste was only exist in the marketing of young coconut ice and young coconut. Even though the risk of coconut shell waste was including in speculation risk but until this time coconut shell waste caused loss for coconut seller. They have to pay for the waste. It reduced the profit of coconut seller.

All sale period in marketing of young coconut ice and young coconut have the same probability for the occuring the risk of coconut shell waste, as much $100 \%$. The highest consequence both marketing of young coconut ice and young coconut were in surplus period, while the lowest consequence were in critical period. The difference amount of purchased coconut in each sale period caused the difference of loss that has been faced by the coconut seller in each sale period. Table 5 showed that the risks at the stage of processing were mapped into three categories: low risk, medium risk, and high risk. The risk of broken coconut on the marketing of grated coconut in all sales periods was mapped at low risk because of probability of occurrence and the consequences are in low category. The risks that need to be paid attention to by seller of coconut product were risk of coconut shell waste, at marketing of young coconut ice and young coconut. Thus, coconut shell waste needs to be managed properly so as not to reduce the convenience of the buyers or reduce the beauty and function of the environment.

\section{The Stage of Selling}

The stage of selling is the part that determines the success of coconut product marketing. Fast sales circulation allows the absorption of the products offered. The high sales rate indicates that the product offered has a good market share. Achieving sales with high profits is determined by the ability of the seller to communicate the value and maintain the relationship that satisfies the customer both before and after the sale transaction. Consumer satisfaction is largely determined by the quality of the sold products, the reasonable price levels, and the services provided.

Consumer satisfaction was a risk source in coconut marketing. It may create failure probability in marketing. Therefore, risk needs to be clearly identified. Several risk at the stage of selling that has been identified could be seen in Table 6 .

Table 6 showed that there were four (4) risks at the stage of selling. It could affect the profit and sustainability of coconut product marketing efforts. Uncertain marketing conditions resulted less sales than expected. It make the sale circulation of coconut fruit to be late and consequently there were unsold for some coconuts that have been processed. Coconut products include non durable products so it must sell fastly. The slow sell circulation caused the quality decrease then price 
decrase and finnally unsold of coconut products. Unsold coconut products was categorized in pure risk, and non transferable risk. It was caused the coconut supply greater than demand, wrong forecasting about demand, also weather and climate.

Table 6: List of Risks at the Stage of Selling

\begin{tabular}{|c|c|c|c|c|}
\hline No. & Risk Register & Risk Type & Risk Source & Product \\
\hline 1. & Unsold product & $\begin{array}{l}-\quad \text { Pure } \\
-\quad \text { Non- } \\
\text { transferable } \\
\text { - Economics }\end{array}$ & $\begin{array}{l}\text { Coconut supply was greater than } \\
\text { demand } \\
\text { Wrong forecasting about demand } \\
\text { Climate and weather constraints }\end{array}$ & $\begin{array}{l}\text { Grated } \\
\text { coconut } \\
\text { Young } \\
\text { coconut ice } \\
\text { Young } \\
\text { coconut }\end{array}$ \\
\hline 2. & $\begin{array}{l}\text { non-strategic } \\
\text { selling locations }\end{array}$ & $\begin{array}{l}\text { Pure } \\
\text { Non- } \\
\text { transferable } \\
\text { Physical }\end{array}$ & $\begin{array}{l}\text { Inappropriate Selection of sales } \\
\text { locations, } \\
\text { Unfavorable market management }\end{array}$ & $\begin{array}{l}\text { Grated } \\
\text { coconut } \\
\text { Young } \\
\text { coconut ice } \\
\text { Young } \\
\text { coconut }\end{array}$ \\
\hline 3. & Substitute goods. & $\begin{array}{l}\text { Dynamic } \\
\text { Non- } \\
\text { transferable } \\
\text { Economics }\end{array}$ & $\begin{array}{l}\text { The higher price level, quality and } \\
\text { quality of substitute goods. }\end{array}$ & $\begin{array}{l}\text { Grated } \\
\text { coconut } \\
\text { Young } \\
\text { coconut ice } \\
\text { Young } \\
\text { coconut }\end{array}$ \\
\hline 4. & Competitors & $\begin{array}{l}-\quad \text { Dynamic } \\
-\quad \text { Transferable } \\
\text { - Economics }\end{array}$ & $\begin{array}{l}\text { The market structure was a perfect } \\
\text { competition market, } \\
\text { Less competitive marketing } \\
\text { strategy. }\end{array}$ & $\begin{array}{l}\text { Grated } \\
\text { coconut } \\
\text { Young } \\
\text { coconut ice } \\
\text { Young } \\
\text { coconut }\end{array}$ \\
\hline
\end{tabular}

Sale location could influence the successful of coconut marketing. Non-strategic sales locations could make low demand for coconut products. The non-strategic selling location was categorized as pure risk. This risk was caused by inappropriate selection of sales locations, as well as less orderly market management. The risk of non strategic sales location was a physical risk that could not be transferred to another party.

Coconut products are human basic needs that can be substituted from other goods. The development of science and technology make the food industry company produce coconut milk instantly packed and durable. It is a substitute goods of grated coconut with a higher and more stable quality. Substitution goods was also phenomenon in processing food and beverage business. Nowdays, we can meet variation of ice beside young coconut ice, such as mixed ice, fruit ice, and others. The risk of substitute goods was a dynamic risk, and no-transferable risk. Its risk source were behavior and economic conditions that was caused by the level price, goods quality, and the strong amount of supply of substitute goods. 
Risk of coconut products at the stage of selling was not only the the risk of substitute goods but also the risk of competitors. Old or new competitior risk must be considerable for existence of the coconut seller. It was a dynamic risk that should be anticipated by sellers of coconut products. The source of competitor risk were perfectly competitive markets structure and less competitive marketing strategies from sellers of coconut products.

Several risks at the stage of selling in coconut products marketing have an impact that could decrease the profit directly. All the risk at the stage of selling have to be calculated the probability of the occurrence and the magnitude of the consequences of the losses it causes to mapping the risk at the stage of selling. It could be seen in Table 7.

Table 7: Mapping of Risk of Coconut Products at the Stage of Selling

\begin{tabular}{|c|c|c|c|c|c|c|c|c|}
\hline \multirow{2}{*}{ No. } & \multirow{2}{*}{$\begin{array}{l}\text { Risk } \\
\text { register }\end{array}$} & \multirow{2}{*}{$\begin{array}{l}\text { Product } \\
\text { type }\end{array}$} & \multirow{2}{*}{$\begin{array}{l}\text { Sale } \\
\text { period }\end{array}$} & \multicolumn{2}{|c|}{ Probability } & \multicolumn{2}{|c|}{ consequence } & \multirow{2}{*}{$\begin{array}{l}\text { Mapping } \\
\text { Risk }\end{array}$} \\
\hline & & & & $(\%)$ & Category & (\$) & Category & \\
\hline \multirow[t]{10}{*}{1.} & \multirow{10}{*}{$\begin{array}{l}\text { Unsold } \\
\text { product }\end{array}$} & \multirow{3}{*}{$\begin{array}{l}\text { Grated } \\
\text { coconut }\end{array}$} & Normal & 0.91 & Low & 4.21 & Low & Low risk \\
\hline & & & Surplus & 0.83 & Low & 6.43 & Low & Low risk \\
\hline & & & Critical & 0.99 & Low & 3.46 & Low & Low risk \\
\hline & & \multirow{3}{*}{$\begin{array}{l}\text { Young } \\
\text { coconut } \\
\text { ice }\end{array}$} & Normal & 14.67 & Low & 49.44 & Low & Low risk \\
\hline & & & Surplus & 16.24 & Low & 97.00 & Low & Low risk \\
\hline & & & Critical & 9.77 & Low & 25.58 & Low & Low risk \\
\hline & & \multirow{4}{*}{$\begin{array}{l}\text { Young } \\
\text { coconut }\end{array}$} & Normal & 15.41 & Low & 106.98 & Low & Low risk \\
\hline & & & Surplus & 18.02 & Low & 274.81 & High & Medium \\
\hline & & & Critical & 14.83 & Low & 64.64 & Low & risk \\
\hline & & & & & & & & Low risk \\
\hline
\end{tabular}

Table 7 showed there was a risk at the stage of selling in coconut marketing that could harm the coconut sellers directly, i.e. unsold coconut products. Generally, the probability and consequence of unsold risk was higher on young coconut marketing in all sale period.

The highest probability of unsold risk of grated coconut was in the critical period, but it has the lowest consequence. While the smallest probability was in the surplus period with the highest consequence. The consequence of unsold products risk in grated coconut marketing could be decreased by copra processed.

Different condition in marketing of young coconut ice and young coconut where the highest probability and also the highest consequence were in the surplus sale periode. While the smallest probability and also the smallest consequence were in the critical sale period.

The risk of unsold young coconut ice occured because the coconut was too young so it could not be processed into young coconut ice. The consequence of unsold products risk in young coconut ice marketing could be decreased by fresh coconut water utilization.

The risk of unsold young coconut occured because the quality of coconut contents 'degan' was not in accordance with the consumer expected. It was a difficult to make sure the quality of coconut content. The consequence of unsold products risk in young coconut marketing could be decreased by creative processing the unexpected coconut content to several processed food. 
The risk of unsold products at the sales stage based on Table 7 was mostly mapped at low risk. This occured in the marketing of grated coconut, coconut ice and young coconut all sales periods, except for the marketing of young coconuts in the surplus sales period mapped to medium risk. It indicated that the risks at the stage of selling were acceptable to sellers of coconut products and did not require special management to minimize those risks. The risks mapped to low categories have no significant effect on sales profits.

\section{Conclusion}

Based on the results it could be concluded several things as follows:

1) The risks of coconut products marketing were identified in the three stages of marketing, namely risk at the stage of purchasing, storaging, processing, and selling.

- Five risks identified at the stage of storaging; broken coconut fruit, unsold product, fire market, theft of coconut fruits, and market regulation.

- Three risks identified at the stage of processing; broken coconut, coconut shell waste, nd damage to processing facilities.

- Four risks identified at the stage of selling; unsold product, non-strategic selling locations, substitute goods, and commpetitors.

2) Overall, the risk on coconut products marketing was mapped at low risk. High risk was more prevalent in the stage of processing, which was caused by the risk of coconut shell waste. While medium risk was more prevalent in the stage of storaging.

\section{References}

[1] Abdullah, W. G. 2015. Manajemen Risiko Agribisnis Gula Merah. Disertasi Program Pascasarjana, Universitas Halu Oleo. Kendari (Tidak dipublikasikan).

[2] Damanik, S. 2007. Strategi Pengembangan Agribisnis Kelapa (Cocos nucifera) untuk Meningkatkan Keuntungan Petani di Kabupaten Indragiri Hilir, Riau. Perspektif, Vol. 6 (2) : 94 104.

[3] Drakel, A. 2010. Kajian Marjin Pemasaran Kopra di Kecamatan Oba di Kota Tidore Kepulauan. Jurnal Ilmiah agribisnis dan Perikanan (agrikan UMMU-Ternate), Vol. 3, (1): 45 - 52.

[4] Fausayana I., Abdullah WG., Susanti F., Sidu D., Arimbawa P., Yunus L. 2017. Factors Affecting the Behavior of Farmers Toward the Risk of Seaweed Farming in the Bungin Permai Village, Southeast Sulawesi, Indonesia. AACL Bioflux, 2017, Vol 10 (6): 1647 - 1653.

[5] Fausayana I., Abdullah WG., Al munir. 2018. Identify and Mapping Risks in the Coconut Brown Sugar Processing Business. AAB Bioflux, 2018. Volume 10 (1) : 1-8

[6] Girdžiūtè, L. 2012. Decision Making in Agriculture and Insurance as A Risk Management Tool. Žemès Ūkio Mokslai, Vol. 19 (1): 45-52.

[7] Hidayat, S., Marimin, A. Suryani, Sukardi, dan M. Yani. 2012. Model Identifikasi Risiko dan Strategi Peningkatan Nilai Tambah pada Rantai Pasok Kelapa Sawit. Jurnal Teknik Industri, Vol. 14 (2): $89-96$.

[8] Jumiati, E., D. H. Darwanto, S. Hartono, dan Masyhuri. 2013. Analisis Saluran Pemasaran dan Marjin Pemasaran Kelapa Dalam di Daerah Perbatasan Kalimantan Timur. Jurnal AGRIFOR, Vol. 12 (1): $1-10$.

[9] Pacific Agribusiness Research \& Development Initiative (PARDI). 2011. Coconut Value Chain Review. The University of Adelaide. Australian Center for International Agricultural Research. Australian Government. Canberra. 
[10] Suharjito, Marimin, Machfud, B. Haryanto, dan Sukardi. 2010. Identifikasi dan Evaluasi Risiko Manajemen Rantai Pasok Produk Jagung dengan Pendekatan Logika Fuzzy. Jurnal Manajemen dan Organisasi, Vol. 1 (2): 118 - 134.

[11] Ruauw, E., J. Baroleh, dan D. Powa. 2011. Kajian Pengelolaan Usahatani Kelapa di Desa Tolombukan Kecamatan Pasan Kabupaten Minahasa Tenggara. ASE, Vol. 7 (2): 39 - 50.

[12] Toledo, R., A. Engler, dan V. Ahumada. 2011. Evaluation of Risk Factors In Agriculture: An Application of The Analytical Hierarchical Process (Ahp) Methodology. Chilean Journal of Agricultural Research, Vol. 71 (1): 114 - 121.

[13] Wowor, L. Y., M. Muis, dan A. R. Arinong. 2007. Analisis Usaha Pembuatan Nata De Coco dengan Menggunakan Sumber dan Kandungan yang Berbeda. Jurnal Agrosistem, Vol. 3 (2): 77 - 86.

[14] Zhang, Y., L. Duan, dan G. Zhang. 2014. Risk Assessment of Agricultural Products Supply-Chain Finance Based on D-S Theory. American Journal of Computational Mathematics, Vol. 5 (4): 366 $-375$.

[15] Zsidisin, G. A., Wagner, S. M., Melnyk, S. A., Ragatz, G. L., and Burns, L. A. 2008. Supply Risk Perceptions and Practices: An Exploratory Comparison of German and US supply Mana-gement Professionals. International Journal of Technology, Policy and Management, Vol. 8 (4): 401 - 419.

\footnotetext{
*Corresponding author.

E-mail address: inefausayana@ ymail.com/wkgusmiarty09@ yahoo.com/ dawidfarid@ yahoo.co.id
} 